\title{
Determination of iron in seawater: From the laboratory to in situ measurements
}

\author{
Mingyue Lin ${ }^{\mathrm{a}, \mathrm{b}, 1}$, Xueping $\mathrm{Hu}^{\mathrm{a}, \mathrm{c}, 1}$, Dawei Pan ${ }^{\mathrm{a}, \mathrm{c}, *}$, Haitao Han ${ }^{\mathrm{a}, \mathrm{c}}$ \\ ${ }^{\text {a }}$ Key Laboratory of Coastal Environmental Processes and Ecological Remediation, Yantai Institute of Coastal Zone Research, Chinese Academy of Sciences, Yantai 264003, \\ PR China \\ ${ }^{\mathbf{b}}$ Research Center for Gold Chemistry, Tokyo Metropolitan University, 1-1 Minami-osawa, Hachioji, Tokyo 192-0397, Japan \\ ${ }^{\mathrm{c}}$ University of Chinese Academy of Sciences, Beijing 100049, PR China
}

A R T I C L E I N F O

\section{Keywords:}

Iron

Determination methods

In situ

Seawater

\begin{abstract}
A B S T R A C T
The marine biogeochemistry of iron plays a significant role in regulating climate change. Trace dissolved iron in oceanic surface water can limit phytoplankton growth which in turn limits the carbon dioxide flux at the air/sea interface. To better understand the relationship between iron and its different species with phytoplankton, as well as the biogeochemical cycle of iron in seawater, accurate, sensitive, and in situ methods are needed for iron determination. This paper reviews the methods for determining iron in seawater from the laboratory, shipboard to in situ measurements, including such strategies as atomic spectrometry, spectrophotometry, chemiluminescence, and voltammetry, which will provide the foundation for developing reliable long-term iron monitoring and sensing platforms in the future.
\end{abstract}

\section{Introduction}

Iron is one of the most abundant elements in the earth's crust (5\%) [1]. However, its concentration in seawater is extremely low $\left(0.1-10 \mathrm{nmol} \mathrm{L}^{-1}\right)$ [2]. Iron is biogenic and plays an important role in photosynthesis because it exists at the active sites of molecules which are responsible for oxygen transport and mitochondrial electron transfer [3], making it an essential trace element for phytoplankton growth in marine ecosystems. Iron bioavailability is thought to be a limiting factor for primary productivity in approximately $40 \%$ of the world's oceans [4], including the subarctic Pacific, the equatorial Pacific, and the Southern Ocean, which are all known as high-nutrient, low-chlorophyll (HNLC) oceanic regions. Even in coastal environments where the total iron concentration is much higher, iron bioavailability is still quite low [5]. If concentrations exceed physical requirements, $\mathrm{Fe}$ may become toxic, acting as an enzyme inhibitor [6] and, moreover, causing oxidative injuries and abnormalities in Fe metabolism, of which the effects may further extend to other biological activities such as behavior, growth, and reproduction [7]. The marine biogeochemistry of iron is highly influenced by its low solubility, redox speciation, and its role in biological cycles [8].

Different species of iron are known to exist in seawater. Historically, different forms of iron were defined as that which passes through a
$0.45,0.4$ or $0.2 \mu \mathrm{m}$ filter membrane. With the development of ultrafiltration technique, the physical-chemical forms of iron are defined as particulate iron $(>0.20 \mu \mathrm{m})$, colloidal iron $(0.02-0.20 \mu \mathrm{m})$, and dissolved iron $(<0.02 \mu \mathrm{m})$ in seawater nowadays [9]. They are dependent on the equilibrium between various particulate and dissolved phases, and the transformation model between the physical-chemical species is shown in Fig. 1. Iron exists in four different states, such as 0 , + II, + III and + VI. The most common species fall under oxidation states + II and + III which can form salts with common anions. Dissolved $\mathrm{Fe}(\mathrm{II})$ and $\mathrm{Fe}(\mathrm{III})$ are believed to be available to biota, while there is no uptake of colloidal or particulate iron in the absence of thermochemical or photochemical dissolution $[10,11]$. This means that increasing the solubility of iron in seawater is likely to increase its bioavailability. The redox transition between oxidation states + II and + III is dependent on $\mathrm{pH}$ and electron activity (pE) [12]. The solubility of $\mathrm{Fe}(\mathrm{III})$ hydroxide in seawater $\left(25^{\circ} \mathrm{C}, \mathrm{pH} 8.1,0.7 \mathrm{~mol} \mathrm{~L}^{-1} \mathrm{NaCl}\right)$ has been reported to be $\sim 10^{-11} \mathrm{~mol} \mathrm{~L}^{-1}$ [13] while the solubility of $\mathrm{Fe}(\mathrm{II})$ is much higher than Fe(III) with respect to thermodynamic properties. However, Fe(II) is easily oxidized to insoluble Fe(III) in oxygen-rich environments [14]. Due to the existence of natural organic Fe chelators in seawater, it is thought that up to $99 \%$ of dissolved iron has complexed with iron-binding ligands [15], indicating that iron redox in seawater is strongly dependent on the concentration and properties of

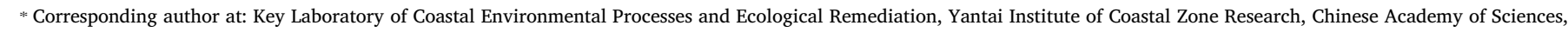
Yantai 264003, PR China.

E-mail address: dwpan@yic.ac.cn (D. Pan).

${ }^{1}$ These authors contributed equally to this work. 


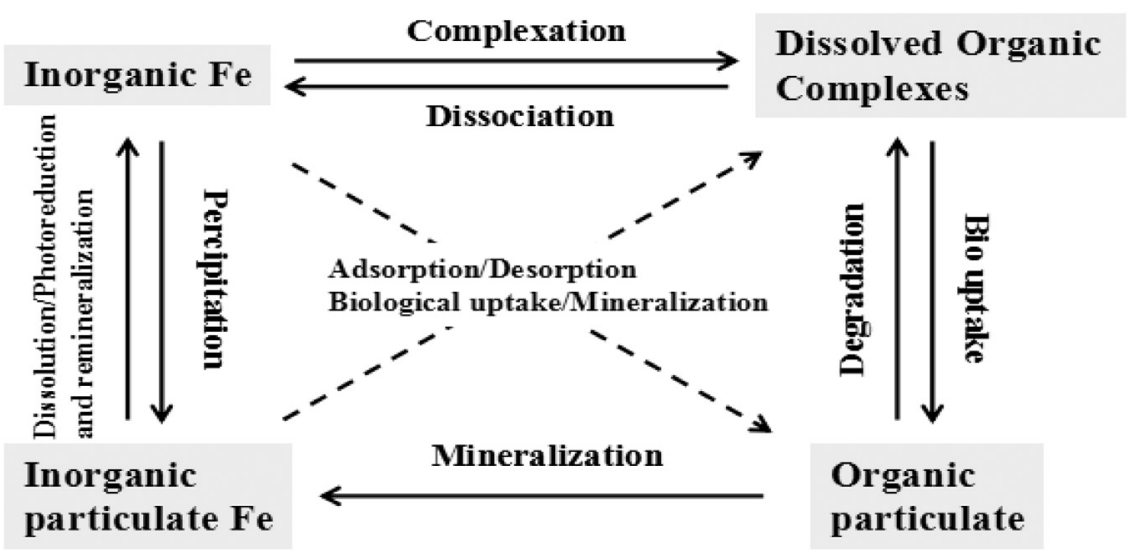

Fig. 1. A diagram of iron phase transfers and related processes in seawater (Reprinted with permission from [10] Copyright ( Elsevier).

these ligands. Strong complexes formed with organic compounds potentially maintain enhanced dissolved Fe concentrations [16] and may permit dissolved Fe concentrations to exceed the solubility product of dissolved inorganic Fe in seawater [17]. In addition, Fe solubility may increase with decreasing temperature, decreasing $\mathrm{pH}$, and decreasing salinity [18]. Thus the concentration of dissolved iron and its different species in seawater play an important role in the growth of marine organisms, influencing the global carbon cycle and consequently global climate change [19]. Hence it is important to understand the marine biogeochemistry of iron, through the accurate determination of trace iron and its speciation in seawater. However, the onboard determination of trace iron, especially its different species in the open ocean, is one of the most challenging problems in marine environment analysis [20].

Determination of iron in seawater has attracted more and more attention recently. In 2014, Worsfold et al. dedicated a review to introduce suitable analytical approaches for determination of dissolved iron in seawater [8], which mainly focused on the processes from sampling and sample treatment, detection methods to quality assurance of the data. In this review, the evolution of the detection method of iron in seawater from the laboratory, shipboard to in situ measurements has been overviewed. Meanwhile, the trends, new detection schemes, features and drawbacks of different analytical methods have been proposed and discussed.

\section{Sampling and sample treatment}

The acquisition and storage of clean and stable samples are key measures that ensure data quality for iron concentrations in seawater. Therefore, there is a need to have a standard protocol. Section 6 of the GEOTRACE program guide [21] contains sampling and handling protocols for trace metals (including iron). In the ocean, preventing sample contamination is the utmost priority. The most commonly used clean sampling systems for vertical profiling are commercial PTFE-lined GoFlo or Niskin samplers with PTFE coated rosette-based systems [22]. Sample handling, reagent preparation, and iron analysis must be conducted under a laminar-flow clean hood with filtered air [23]. Sample storage requires ultra-clean containers. Low-density polyethylene (LDPE) and high-density polyethylene (HPDE) bottles are recommended for trace iron determination [21]. These containers must be thoroughly cleaned using an acidic solution according to the recommended protocols [21].

For samples used for total dissolved iron content, the samples need to be acidified to $\mathrm{pH}<2.0$ using a guaranteed pure $\mathrm{HCl}$ or $\mathrm{HNO}_{3}$ solution that has been re-distilled on a cold finger silica distillation apparatus or Teflon stills [23]. To analyze the different species of iron, reagents used to determine their distribution $[24,25]$ or the direct determination of Fe(II) should be carried out immediately after sampling and measured onboard the ship due to the high reactivity of certain iron species, especially $\mathrm{Fe}(\mathrm{II})$.

\section{Laboratory methods}

\subsection{Atomic spectrometry}

The most common method used to determine iron in seawater requires pre-concentration coupled with atomic spectrometry, such as atomic absorption spectrometry (AAS), inductively coupled plasma mass spectrometry (ICP-MS), and so on. The most popular solvent extraction method was reported by Bruland et al. [26] in 1979 with a double extraction into chloroform after chelating with ammonium 1pyrrolidinedithiocarbamate (APDC) and diethylammonium diethyldithiocarbamate (DDDC), then back-extraction into nitric acid. A detection limit of 50 pmol. $\mathrm{L}^{-1}$ for graphite furnace atomic absorption spectrometry (GFAAS) using the above solvent extraction pre-concentration was reported by Landing and Bruland in 1987 [27]. On-line solid phase pre-concentration gained increasing attention in the late 1980s [28] after a detection limit of $150 \mathrm{pmol} \mathrm{L}^{-1}$ was reported by Saager et al. [29], based on a Chelex-100 column for GFAAS. However, these methods usually required samples greater than $250 \mathrm{~mL}$ and determination was limited by high reagent blank concentrations and contamination [26].

Thus, how to improve the detection limit and decrease the volume of sample used have been the main direction for research in determining iron in seawater by atomic spectroscopy. High resolution (magnetic sector) ICP-MS with high sensitivity and a short detection time has recently become widely used to lower the detection limit and improve the detection sensitivity [30-32]. Isotope dilution is now frequently used for quantification because it does not require standard addition or external standards that can greatly minimize the deviation due to matrix interference and recovery variations [8]. The co-precipitation pre-concentration methods required minimal use of reagents, which therefore can significantly lower the reagent blanks [32]. The task-specific ionic liquid (TSIL) of 1-ethyl-3-methylimidazolium bromide functionalized with 8-hydroxyquinoline was used as a chelating agent and extracting solvent for dispersive liquid-liquid micro-extraction offers advantages such as simplicity, ease of operation [33]. Based on the above advantages, the lowest detection limit for atomic spectrometry is $2 \mathrm{pmol} \mathrm{L}^{-1}$ using a magnesium hydroxide co-precipitation method with a high resolution ICP-MS reported by Wu [34], or $14 \mathrm{pmol} \mathrm{L}^{-1}$ by using a Nobias Chelate PA1 resin that has been coimmobilized with ethylenediaminetriacetic acid and iminodiacetic acid on a high resolution ICP-MS reported by Biller and Bruland [30]. The minimum required sample volume was $12 \mathrm{~mL}$ using isotope dilution with a high resolution ICP-MS method, reported by Milne et al. [31]. A novel automated off-line preconcentration system for trace metals (Al, 
$\mathrm{Mn}, \mathrm{Fe}, \mathrm{Co}, \mathrm{Ni}, \mathrm{Cu}, \mathrm{Zn}, \mathrm{Cd}$, and $\mathrm{Pb}$ ) in seawater was developed through improving a commercially available solid-phase extraction system SPE100 (Hiranuma Sangyo). The nine trace metals were simultaneously and quantitatively pre-concentrated from $120 \mathrm{~g}$ of seawater by the single-step preconcentration combined with high-resolution ICP-MS [35]. Significant improvements have been made in the determination of iron in seawater using atomic spectrometry, but cumbersome equipment and complex pre-treatment as well as expensive costs for testing restrict its application in situ use at sea. This is more commonly an analysis reserved for laboratories on land in a controlled environment. Additionally, atomic spectrometry can only determine the total dissolved iron.

\subsection{Spectrophotometry}

Spectrophotometric techniques involve ligands that can selectively combine with iron (a particular redox state) to form a colored complex with high molar absorptivity. The initial ligands that were used for iron determination were 2,2',2'-tripyridyl [36], 2,2'-bipyridyl [37], and thiocyanate [38]. Total dissolved iron was determined after the reduction of Fe(III) and these ligands were used to bind Fe(II). Later, more selective and sensitive ligands for iron complex, such as 1,10-phenanthroline [39], 2,4,6-tripyridyl-1,3,5-triazine [40], and bathophenanthroline [41], were used for iron spectrophotometric determination. Although the spectrophotometric method has the advantage of being an inexpensive and simple procedure, its sensitivity does not meet the requirements for determining trace iron in seawater directly. Thus, more selective and sensitive ligands have been developed to meet the required limits of detection. A chelating resin is definitely needed for $\mathrm{Fe}$ determination. One reason is to pre-concentrate iron while another is to separate it from the bulk seawater matrix. The most widely used functional chelating group is 8-Hydroxyquinoline (8-HQ), which is immobilized on a vinyl polymer resin. Many chelating resins, such as Toyopearl TSK [42], Toyopearl AF-Chelate-650 [43], and NTA "Superflow" [44], are commercially available. Ferrozine (3-(2-bipyridyl)5,6-bis(4-phenylsulfonic acid)-1,2,4-triazine) has been widely used in $\mathrm{Fe}(\mathrm{II})$ determination because it can form a colored stable Fe(II)-ferrozine complex with high molar absorptivity $(\lambda=562 \mathrm{~nm})$ [45]. Blain and Treguer [46] used ascorbic acid to reduce $\mathrm{Fe}(\mathrm{III})$ to $\mathrm{Fe}(\mathrm{II})$ and calculated the total dissolved iron. Using this on-site reduction system, one can obtain the redox speciation of Fe(III), Fe(II), and total dissolved iron. The drawback of the spectrophotometric method is that the complexing ligand (such as ferrozine) may change the iron redox speciation under certain conditions [47]. Another thing to point out is that $\mathrm{pH}$ is an important parameter for the recovery of $\mathrm{Fe}(\mathrm{III})$ and $\mathrm{Fe}(\mathrm{II})$ from the pre-concentration column. Obata et al. [48] reported that Fe(III) can be collected from 8-HQ at $\mathrm{pH}$ 3.0-4.2 while Fe(III) and Fe(II) can be recovered at pH 5.2-6.0. In ferrozine methods, sample acidification can also promote the reduction of $\mathrm{Fe}(\mathrm{III})$ to $\mathrm{Fe}(\mathrm{II})$, which will change the redox speciation. For these reasons, how to quickly determine transient $\mathrm{Fe}(\mathrm{II})$ in un-acidified samples for iron redox analysis is still a challenge.

Except for the ferrozine method, the catalytic oxidation of DPD (N,N-dimethyl-p-phenylenediamine dihydrochloride) by $\mathrm{Fe}(\mathrm{III})$ in the presence of $\mathrm{H}_{2} \mathrm{O}_{2}$ [49,50] is also a widely used spectrophotometry method for iron determination. DPD can be oxidized by Fe(III) and $\mathrm{H}_{2} \mathrm{O}_{2}$ is introduced to ensure all iron in the solution has been transformed into Fe(III). The amount of oxidized DPD can be detected spectrophotometrically $(\lambda=514 \mathrm{~nm})$ [51] and it is proportional to the concentration of iron. The disadvantage of catalytic DPD method is that it cannot determine redox iron speciation.

\subsection{Chemiluminescence}

The most popular chemiluminescence (CL) reaction, luminol (5amino-2,3-dihydro-1,4-phthalazinedione)- $\mathrm{H}_{2} \mathrm{O}_{2}$, has been widely applied in the detection of various substances [52]. O'Sullivan et al. [53] and King et al. [54] adapted the chemiluminescence technique for use in seawater and luminol-CL reactions have been used for trace iron determination in seawater based on the catalytic effect of either Fe(III) or $\mathrm{Fe}(\mathrm{II})$ on the oxidation of luminol to generate blue luminescence $(\lambda$ $\sim 440 \mathrm{~nm}$ ). In addition to luminol, brilliant sulfoflavin (4-amino- $N-p$ tolyl)-naphthalimide-3-sulfonate was also used for Fe(II) and total dissolved iron determination in seawater $[55,56]$. Prior to determining the total dissolved iron, a reducing agent (eg. ascorbic acid) was needed to reduce $\mathrm{Fe}(\mathrm{III})$ to $\mathrm{Fe}(\mathrm{II})$.

Chemiluminescence is often used along with flow injection analysis (FIA) technology in the determination of iron. For laboratory experiment, the main purpose of using chemiluminescence method is to constrain iron concentrations within seawater kinetic models. Rose and Waite [57] used luminol-CL method to measure Fe(II) and developed a detailed kinetic model to understand the oxidation process of $\mathrm{Fe}(\mathrm{II})$ in seawater in the absence and presence of natural organic matter. Results showed that the presence of a relatively strong Fe(III) binding ligand significantly increased the rate of Fe(II) oxidation, while ultimately retaining most of the iron in the system in dissolved form.

\subsection{Voltammetry}

Accurate determination and quantification is required for trace iron and its species in seawater. Compared to other analytical methods, such as spectrometry $[26,27,30,31]$, spectrophotometry $[45,46,48]$, and chemiluminescence [58], voltammetry has the advantage of being low cost, simple, fast, highly sensitive, and it can determine trace iron and iron species in seawater. The low solubility of iron in mercury [59] and the direct reduction of Fe(III) to element metal coincides with the hydrogen reduction in an acidic solution [60]. This limits the voltammetric stripping of iron via metal and also means that iron can't be quantified using conventional anodic stripping voltammetry. Thus, the electrochemical methods used to determine iron content can be divided into two groups: one is based on the direct reduction reaction of Fe(III) to $\mathrm{Fe}(\mathrm{II})$ on the working electrode, and the other is based on adsorptive cathodic stripping voltammetry, in which an iron-binding ligand is added to form a complex with Fe(III) and analysis is performed on the cathodic stripping of the Fe(III)-complex. Competitive ligand adsorptive cathodic stripping voltammetry can also be used to analyze different species of iron.

A key issue in the quantitative analysis of iron based on the direct reduction of $\mathrm{Fe}(\mathrm{III})$ is how to improve the sensitivity, stability, and antiinterference ability of the working electrode. Štulíková and Vydra [59] used a rotating carbon disk electrode to cathodically detect Fe(III) with a detection limit of $0.1 \mu \mathrm{mol} . \mathrm{L}^{-1}$ in acidic media after deaeration. But the detection limit was too high for trace iron determination in seawater, indicating that the working electrode needed to be modified. Pan's group recently have developed a series of modified electrodes to sensitively and selectively detect total dissolved iron in coastal waters without using complexing ligands [61-65]. For example, Lin et al. [64] used a nanocomposite of reduced graphene oxide/methylene blue/gold nanoparticles to modify GCE and the sensitive cathodic signal of Fe(III) was achieved with a detection limit of $15 \mathrm{nmol} \mathrm{L}^{-1}$ in $0.1 \mathrm{M} \mathrm{HCl}$ without requiring the use of complexing ligands for Fe(III). Li et al. [63] reported a sensitive determination of Fe(III) in coastal waters based on ionic liquid-reduced graphene oxide-supported gold nanodendrites with a detection limit of $35 \mathrm{nmol} \mathrm{L}^{-1}$. Han et al. [61] achieved a controlled synthesis of dendritic gold nanostructures using graphene oxide on GCE and a morphology-dependent performance for Fe(III) determination with a detection limit of $15 \mathrm{nmol} \mathrm{L}^{-1}$. Lin et al. [65] took advantage of the synergistic effects between titanium carbide nanoparticles and Nafion to modify GCE and the catalytic amplifying effect of oxidant hydrogen peroxide, achieving a detection limit of $7.2 \mathrm{nmol} \mathrm{L}^{-1}$ for Fe (III). Hu et al. [62] used a graphene oxide-assisted synthesis of bismuth nanosheets, modified GCE, and oxidant $\mathrm{KBrO}_{3}$ to catalytically detect $\mathrm{Fe}$ (III) at a limit of $2.3 \mathrm{nmol} \mathrm{L}^{-1}$. To date, the determination of iron based 
on the direct reduction of Fe(III) without any complexing ligands has been widely used in laboratory measurements for total dissolved iron because it is easy, cheap and sensitive.

The electrochemical determination of total dissolved iron based on direct measurement of $\mathrm{Fe}(\mathrm{III})$ has the advantage of being inexpensive, simple, fast, and sensitive, but the detection limitations cannot meet some of the requirements of trace iron in seawater and may be complicated by interference in seawater samples. Adsorptive cathodic stripping voltammetry based on the signal of iron-binding ligands provides a good solution to this problem. The chelating reagents include catechol [66], salicylaldoxime [67], 1-nitroso-2-napthol [68], 2(2-thiazolylazo)-p-cresol [69], and 2,3-dihydroxynaphthalene $[20,23,70]$. In addition, the sensitivity can be catalytically increased by adding oxidizing agents, such as $\mathrm{H}_{2} \mathrm{O}_{2}, \mathrm{KBrO}_{3}, \mathrm{ClO}_{2}^{-}[25,68]$. The most sensitive method for iron determination in seawater was reported by Laglera using 2,3-dihydroxynaphthalene as the complexing ligand and $\mathrm{KBrO}_{3}$ as the oxidizing agents, with a detection limit of $5 \mathrm{pmol} \mathrm{L}^{-1}$ for Fe(III) [20]. The ligands mentioned above typically use a mercury electrode as the working electrode. Mercury electrodes are well known for their toxicity and the inconvenience associated with handling them [71], which restrict their wider use, especially onboard determination. Bismuth is the most popular alternative mercury-free electrode material and has been widely used in the determination of iron with help of complexing ligands. Segura et al. [72] used 1-(2-piridylazo)-2-naphthol (PAN) as the complexing ligand for Fe(III), and Fe(III)-PAN was adsorbed onto a bismuth-coated GCE with a $60 \mathrm{~s}$ adsorption time followed by square wave cathodic stripping voltammetry to obtain a detection limit of $1.79 \mathrm{nmol} \mathrm{L}^{-1}$. Lin et al. [73] introduced a new environmentally-friendly electrode called a tin-bismuth alloy electrode to solve some of the differences in determination due to the inhomogeneous bismuth film and the plating potential and substrate electrode depended morphology. They also chose PAN as the Fe(III) complexing ligand and obtained a detection limit of $0.2 \mathrm{nmol} \mathrm{L}^{-1}$ using differential pulse adsorptive stripping voltammetry with an adsorption time of $60 \mathrm{~s}$. Bobrowski et al. [74] used triethanolamine (TEA) as the Fe (III) complexing ligand and $\mathrm{KBrO}_{3}$ to rapidly oxidize $\mathrm{Fe}(\mathrm{II})-\mathrm{TEA}$ to $\mathrm{Fe}$ (III)-TEA, therefore achieving a detection limit of $7.7 \mathrm{nmol} \mathrm{L}^{-1}$ on a bismuth film electrode in alkaline solution. Zhu et al. [75] utilized a GCE modified with reduced graphene oxide and gold nanoparticles and the complexing ligand 2-(5-bromo-2-pyridylazo)=5-diethylaminophenol (5-Br-PADAP) to detect total dissolved iron in coastal waters, reporting a detection limit of $3.5 \mathrm{nmol} \mathrm{L}^{-1}$. Lin et al. [76] used 2,2'bipyridyl as the complexing ligand for Fe(II) and achieved a sensitive determination for $\mathrm{Fe}(\mathrm{II})$ in coastal waters based on titanium carbide nanoparticles/Nafion/platinum nanoflowers modified GCE with the lowest detectable concentration of $0.1 \mathrm{nmol} \mathrm{L}^{-1}$.

Another significant advantage of the electrochemical method compared to other analytical methods for iron determination in seawater is that it can be used to determine iron speciation. It is very important to determine the iron species because iron is thought to be a limiting nutrient for phytoplankton growth, while Fe(II) might be a preferred nutrient [77]. The biological role of iron-binding ligands and the rate at which organically bound iron becomes bioavailable require more investigation because some ligands, like siderophores and porphyrins, may be selectively released by organisms and can organically complex with dissolved iron [78]. Additionally, little is known about the speciation of $\mathrm{Fe}(\mathrm{II})$ in seawater and the extent to which $\mathrm{Fe}(\mathrm{II})$ is organically complexed. Understanding the different species of iron found in seawater is needed to better understand the effect of organic complexation on iron bioavailability and the biogeochemical cycling of iron. To obtain the concentration of labile iron, voltammetric determination was used to compare the natural and added ligands using cathodic stripping voltammetry $[67,68]$. The equation can be described as $\left[\mathrm{Fe}^{3+}\right] /[\mathrm{Fel}]=\left[\mathrm{Fe}^{3+}\right] / C_{\mathrm{L}}+1 /\left(K_{\mathrm{Fel}} C_{\mathrm{L}}\right)$, where $[\mathrm{FeL}]$ is the concentration of iron complexed with the natural ligand $\mathrm{L}, C_{\mathrm{L}}$ is the total concentration of L, and $K_{\mathrm{FeL}}$ ' is the conditional stability constant of [FeL] [68].
This titration experiment can be carried out onboard and has been widely applied in onboard measurements of trace iron and iron speciation $[23,70]$.

\section{Shipboard methods}

Requirements for portable methods that are suitable for onboard use at sea are intended to simplify sample pre-treatment and minimize sample storage. FIA has the advantage of easy automatic operation and high sample throughput, which provides an excellent platform for sample handling [79]. Recently, FIA has been widely used for shipboard measurements of iron in conjunction with other detection methods, especially for iron redox speciation analysis because it can greatly minimize the redox change and contamination. The primary detection methods are spectrophotometry (SP) and chemiluminescence (CL) and voltammetric method. Typical flow injection manifolds for the determination of iron based on FIA-SP and FIA-CL [80] are shown in Fig. 2.

\subsection{Flow injection with spectrophotometry}

FIA using on-line pre-concentration provides an excellent platform for sample handing. One reason is to pre-concentrate iron while another is to separate it from the bulk seawater matrix. King et al. [81] used a $\mathrm{C}_{18}$ column with ferrozine to pre-concentrate $\mathrm{Fe}(\mathrm{II})$, then spectrophotometrically detected the iron concentration in the solution to elute the complex from the $\mathrm{C}_{18}$ column. Later, O'Sullivan et al. [82] added an in situ sampling system to the detection system described above for onsite determination. They studied the Fe(II) distribution in the equatorial Pacific and found that concentrations varied from 120 to $500 \mathrm{pmol} \mathrm{L}^{-1}$. Measures et al. [49] reported a detection limit of $25 \mathrm{pmol}^{-1} \mathrm{~L}^{-1}$ using FIA equipped with an 8-HQ micro-column. Lohan et al. [50] reported a detection limit of $24 \pm 4.9 \mathrm{pmol} \mathrm{L}^{-1}(n=9)$ for Fe based on the FIADPD method. For seawater samples collected in the North Pacific Ocean, the average concentration of total dissolved iron in the surface samples was $0.101 \pm 0.009 \mathrm{nmol} \mathrm{L}^{-1}(n=14)$ and in samples from $1000 \mathrm{~m}$ in depth was $0.93 \pm 0.04 \mathrm{nmol} \mathrm{L}^{-1}(n=18)$.

Recently, another spectrophotometrical technique that uses a long path length liquid wave guide capillary cell (LWCC) has been widely used to lower the detection limit of iron. The detection mechanism is same as the spectrophotometric methods described above. Zhang et al. [83] used a ferrozine method combined with a $2 \mathrm{~m}$ LWCC for iron speciation in seawater with a detection limit of $0.1 \mathrm{nmol} \mathrm{L}^{-1}$. Huang et al. [84] used ferrozine as the complexing ligand and LWCC as the detection technique to carry out real time redox speciation (Fe(II), $\mathrm{Fe}$ (III), Fe(II + III)) of iron in the surface waters of the East China Sea. The biggest advance was that they updated the single carrier stream design (as shown in Fig. 2a) to dual carrier streams to minimize the Schlieren effect caused by the variation in salinity (as shown in Fig. 3).

In addition to normal FIA (nFIA), a reverse FIA (rFIA) method reported by Huang et al. [85] has been used to determine the total dissolved iron in estuarine and coastal waters collected from the Pearl River Estuary based on DPD methods. The detection limit was $0.4 \mathrm{nmol} \mathrm{L}^{-1}$, which was lower than half of that of the nFIA method. Fig. 4 shows the manifold of this rFIA system. The difference between nFIA and rFIA is that rFIA uses samples as the carrier and the reagents are injected into the carrier, which is opposite of the nFIA procedure [85]. rFIA consumed less reagents and the sample throughput of rFIA $\left(10 \mathrm{~h}^{-1}\right)$ was much higher than in the nFIA $\left(4 \mathrm{~h}^{-1}\right)$ method, so rFIA is believed to be more suitable for long-term shipboard use.

\subsection{Flow injection with chemiluminescence}

FIA-CL is a sensitive method that has been developed to determine iron in seawater. Careful adjustment of the $\mathrm{pH}$ and an on-line preconcentration with 8 -HQ $[25,86]$ to remove matrix and pre-concentrate 


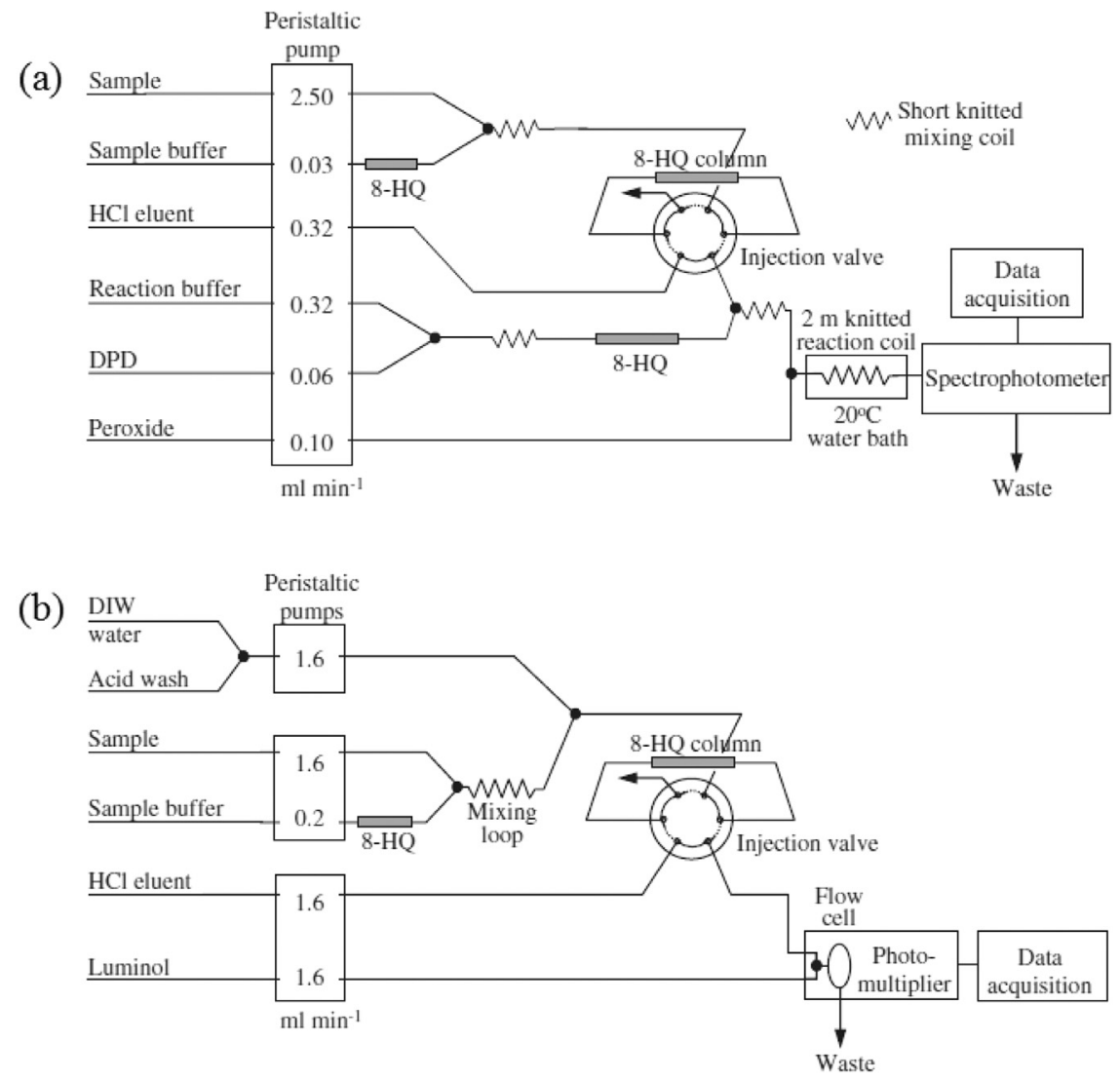

Fig. 2. The typical flow injection manifolds for iron determination based on (a) FLA-SP and (b) FLA-CL (Reprinted with permission from [80] Copyright (C) John Wiley and Sons).

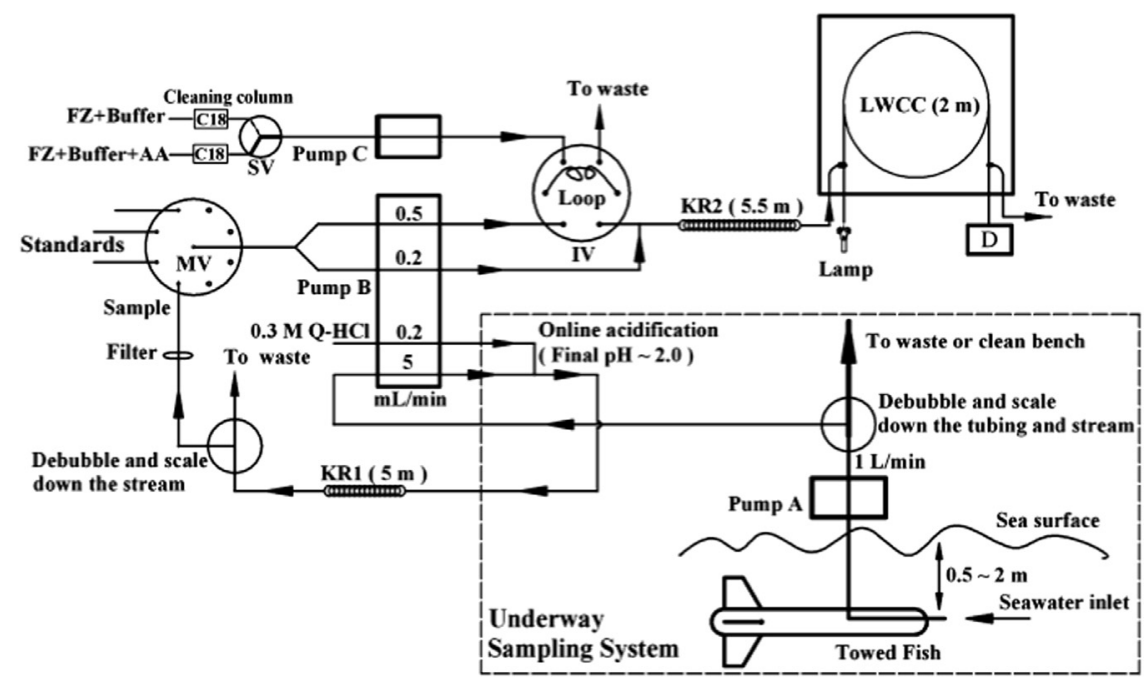

Fig. 3. The manifold configuration of real-time iron speciation system based on Fe(II)-ferrozine and LWCC (Reprinted with permission from [84] Copyright (C) American Chemical Society).

iron are needed to achieve the highest sensitivity and avoid precipitation [87]. Bowie et al. [58] reported a sensitive onboard determination system for Fe(II) and total dissolved iron based on a FIA-luminol-CL method with a detection limit of $40 \mathrm{pmol} \mathrm{L}^{-1}$ (3 s). As shown in Fig. 5 , an off-line reduction of Fe(III) to Fe(II) in acidified samples was conducted first, followed by an in-line matrix elimination and pre-concentration on an 8-HQ column under $\mathrm{pH} 5.0$ as well as merging with a luminol/carbonate buffer reagent stream to detect the total dissolved iron after eluting $\mathrm{Fe}(\mathrm{II})$ from the resin using $\mathrm{HCl}$.
The manifold for Fe(III) and total dissolved iron determination based on the FIA-luminol- $\mathrm{H}_{2} \mathrm{O}_{2}$-CL method is shown in Fig. 6 [48]. Acidified samples are firstly oxidized from Fe(II) to Fe(III) off-line by $\mathrm{H}_{2} \mathrm{O}_{2}$, then buffered to a $\mathrm{pH}$ of 3.0 in-line prior to pre-concentration. After eluting $\mathrm{Fe}(\mathrm{III})$ from the resin using $\mathrm{HCl}$, streams of luminol/carbonate and $\mathrm{Fe}(\mathrm{III})$ with $\mathrm{H}_{2} \mathrm{O}_{2}$ are mixed for detection by a photomultiplier tube [88]. Klunder et al. [88] used the FIA-luminol- $\mathrm{H}_{2} \mathrm{O}_{2}-\mathrm{CL}$ method with pre-concentration on an iminodiacetic acid (IDA) resin to detect Fe(III). The detection limit of this method was 


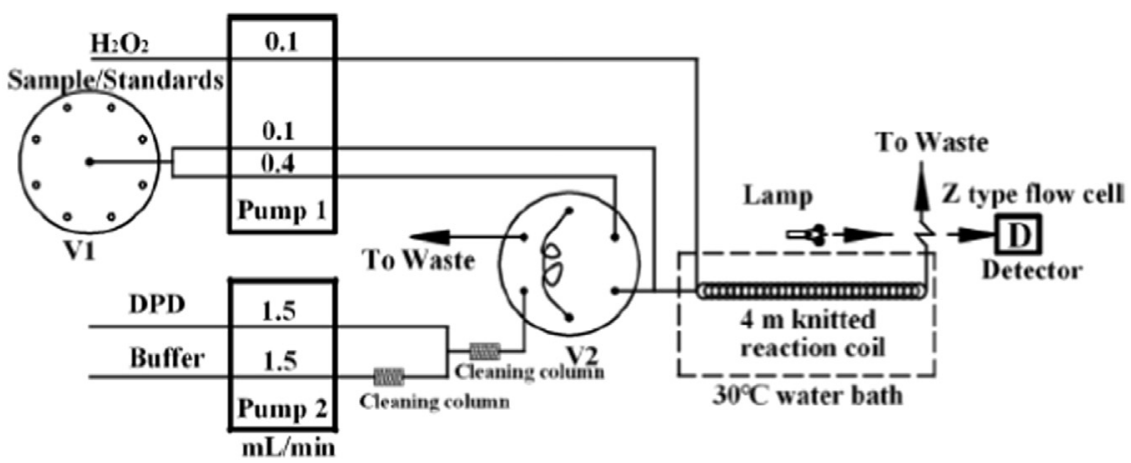

Fig. 4. The manifold configuration of rFIA based on DPD and the $\mathrm{H}_{2} \mathrm{O}_{2}$ method (Reprinted with permission from [85] Copyright (C) Elsevier).

$5.7 \pm 2.9 \mathrm{pmol} \mathrm{L}^{-1}$ and it has been applied for shipboard use to accurately determine the distribution of dissolved iron in the southern Atlantic Ocean. Cannizzaro et al. [89] determined the total dissolved iron in Tamar Estuary (UK) with a detection limit of $40 \mathrm{pmol} \mathrm{L}^{-1}(3 \mathrm{~s})$ using a luminol reaction with dissolved oxygen as the oxidant to replace $\mathrm{H}_{2} \mathrm{O}_{2}$ based on flow injection. Oliveira et al. (2015) developed a preliminary protocol for $\mathrm{Fe}(\mathrm{II})$ determination in acidified seawater based on the reaction between $\mathrm{Fe}(\mathrm{II})$ and luminol. They proposed a novel micro-sequential injection ( $\mu \mathrm{SI})$ fluidic protocol and two distinct strategies for photon collection, that was the first application of chemiluminescence detection under lab-on-valve (LOV) format [90]. The longterm stability of luminol solution and its low consumption per determination $(100 \mu \mathrm{L})$, combined with the rapid analytical throughput (116 determinations per hour), make this approach well suited to shipboard analysis of Fe(II) with potential for autonomous operations.

\subsection{Flow injection with voltammetry}

Voltammetry has recently been found to be useful in the on-site determination of trace metals [91-94]. It does not require a matrix removal step and can be used for the determination of a wide range of metals, which can greatly simplify the procedure and minimize the contamination and redox change in pre-treatment [95] to improve iron determination in situ. Fig. 7 shows the manifold of an automated voltammetric system that has already been used for shipboard analysis of trace metals. Achterberg and van den Berg [91] applied this in-line automated voltammetric system to determine the total dissolved $\mathrm{Cu}$ and $\mathrm{Ni}$ in the North Atlantic and Western Mediterranean. They later [92] introduced complexing ligand titrations to this system and were able to automatically record reliable copper concentrations (in the Atlantic Ocean) and redox chromium types (in the Mediterranean) based on the differentiate between $\mathrm{Cr}(\mathrm{III})$ and $\mathrm{Cr}(\mathrm{VI})$ using onboard adsorption of $\mathrm{Cr}$ (III) on silica particles. The working electrode used in this system was a hanging mercury electrode [91,92]. Mikkelsen et al. introduced an automatic monitoring system for the continuous monitoring of $\mathrm{Zn}$ and $\mathrm{Fe}$ in river water, drainage water, and waste water at low concentrations [96]. The manifold of this system is shown in Fig. 8. The working electrode that used was a dental amalgam electrode (DAM, $d \approx 2.5 \mathrm{~mm}$ ), an environmentally-friendly alternative to the liquid mercury electrode in the field. The detection strategy was based on the re-oxidation of iron deposited on a solid amalgam electrode surface and had a stripping peak of iron at around $-0.65 \mathrm{~V}$. The frequency of maintenance required for this system varied from once a week in wastewater to once a month in river water. Those automated voltammetric determination of trace metals discussed above can provide feasible solutions to realize the in situ analysis of iron in seawater. Additionally, the Au-Hg microelectrode has also been used for in situ measurements of $\mathrm{Fe}[97,98]$. It has been used to detect $\mathrm{Fe}(\mathrm{II})$ with a detection limit of $25 \mu \mathrm{mol} \mathrm{L}{ }^{-1}$ in seawater [97] and $10 \mu \mathrm{mol} \mathrm{L}^{-1}$ in freshwater due to the elimination of sodium interference [98].

\subsection{Flow injection with other methods}

Multisyringe flow injection analysis (MSFIA) was established combining the advantages of several techniques: working in parallel like FIA, robust like sequential injection analysis (SIA), and using solenoid valves like multi-commutation flow injection analysis (MCFIA) [99]. Few works have been established by coupling of MSFIA systems with atomic absorption spectrometry (AAS). MSFIA systems coupled with hydride generation atomic fluorescence spectrometry (HG-AFS) have been often employed for the determination and speciation analysis of elements $[35,99,100]$. A 3D printed device with a disk-based solidphase extraction for the automated speciation of iron using the multisyringe flow injection analysis technique has been reported by Calderilla et al. [101]. Using 3D printing techniques has the advantages of being simple, fast and low-cost. Thus, it is highly desirable for the development of novel devices. In addition, integrated 3D printed devices are a step forward toward the full reproducibility of complex flowbased networks for automated in situ chemical analysis.

\section{In situ methods}

Carrying out the in situ analysis of iron speciation is an important component of research on the iron biogeochemical cycle. However, ICPMS and AAS have a limited range for use and are not suitable for on-site measurement. Colorimetry and chemiluminescence combined with FIA have a lower detection limit for iron and can determine redox iron species, but they require complicated pre-concentration procedures and matrix removal. Voltammetric techniques are very suitable to design probes for trace metal analysis and can analyze a large number of trace compounds at low detection limit, while also measuring different iron species based on the redox state and liability of metal species [102].

However, many applications were limited to short-term in situ analysis in surface waters. Long-term voltammetric monitoring at different depths faces challenges such as insufficient reliability of sensors, fouling of the sensor surface, interferences from dissolved oxygen and pressure, and more [102]. The Voltammetric In Situ Profiling System (VIP system) firstly developed by Tercier et al. [103] provides a solution to the above problems and has now been commercialized for continuous in situ analysis of trace metals [94,103,104]. The manifold of the VIP system is shown in Fig. 9(A). The VIP system contains a submersible voltammetric probe, a multi-parameter probe (including temperature, salinity, pressure, conductivity, $\mathrm{O}_{2}$, and $\mathrm{pH}$ ), an on-line $\mathrm{O}_{2}$ removal module, and a telemetry unit connected to a laptop computer, and it can also be controlled onboard or automatically following preprogrammed instructions. The electrochemical measurements are conducted within a mini-voltammetric cell (internal volume of $1.5 \mathrm{~mL}$ ) and the gel-integrated microelectrode (GIME) is used as the working electrode. The GIME is a Hg-plated-Ir microelectrode covered by an agarose gel that functions as a small separation/reaction chamber with fast diffusion transport and also protects the surface from fouling [103]. The 


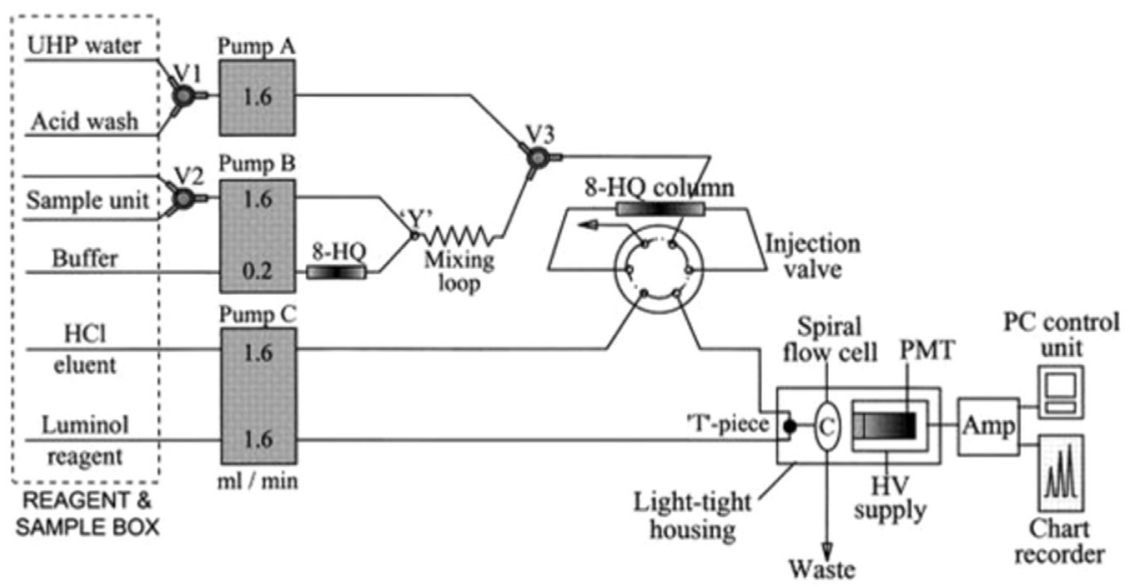

Fig. 5. The manifold for determination of Fe(II) and total dissolved iron based on the FIA-luminol-CL method (Reprinted with permission from [58] Copyright @ Elsevier).

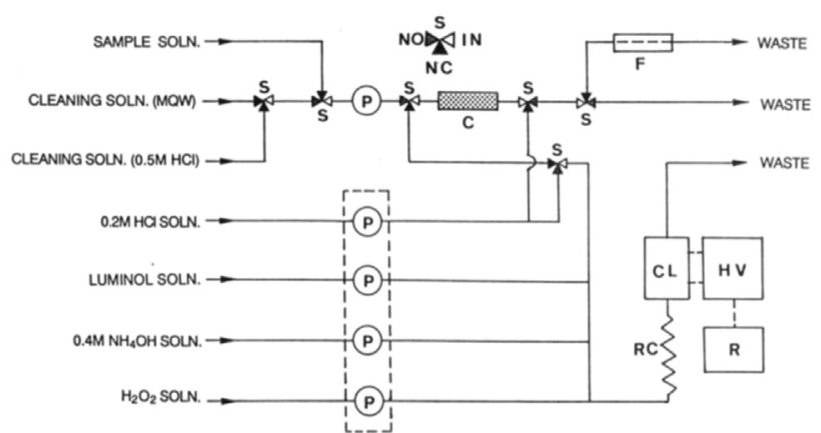

Fig. 6. The manifold for $\mathrm{Fe}(\mathrm{III})$ and total dissolved iron determination based on the FIA-luminol- $\mathrm{H}_{2} \mathrm{O}_{2}$-CL method (Reprinted with permission from [48] Copyright (c) American Chemical Society).

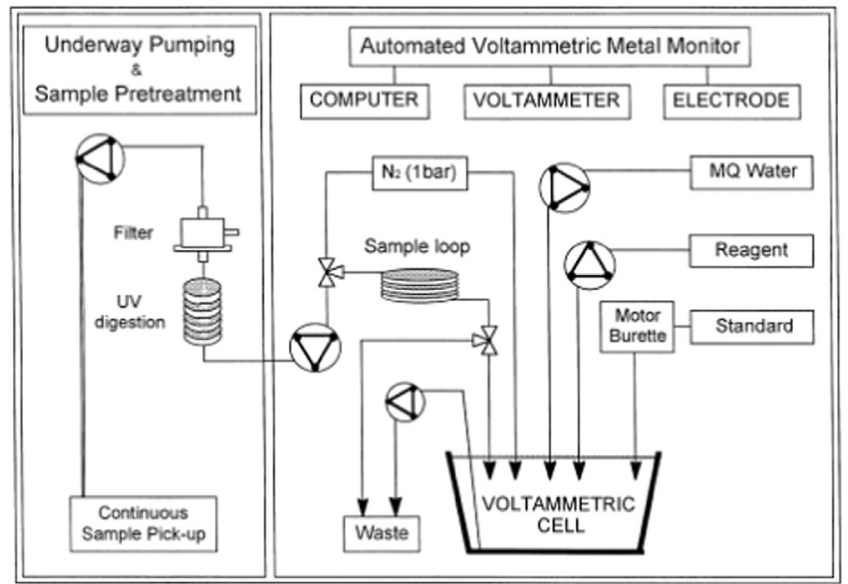

Fig. 7. The manifold of an automated voltammetric system for shipboard analysis of trace metals (Reprinted with permission from [91,92,95] Copyright (c) Elsevier).

voltammetric analysis is performed after a $5-10$ min' equilibration period in the agarose gel (typically for a membrane of $300 \mu \mathrm{m}$ ) with the solution [102]. The detection limits for square wave cathodic stripping voltammetry measurements of $\mathrm{Fe}(\mathrm{II})$ and $\mathrm{Mn}(\mathrm{II})$ based on the interconnected GIME were $1 \mu \mathrm{mol} \mathrm{L}^{-1}$ and $0.1 \mu \mathrm{mol} \mathrm{L}^{-1}$, respectively [104]. The GIME can also be modified with a thin layer (a few $\mu \mathrm{m}$ ) of a complexing resin called CGIME [105] to achieve sub-nanomolar detection of free metal-ions in complicated systems. Different from measurements using GIME, an additional step is needed to release the trace

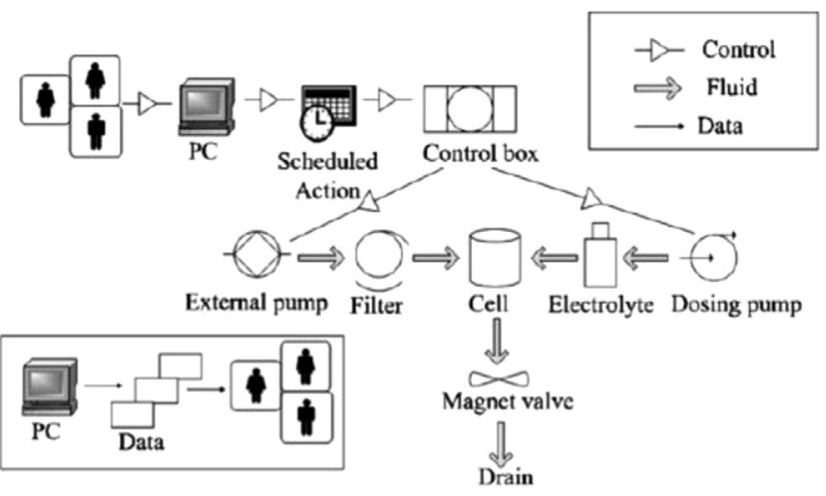

Fig. 8. The manifold of Mikkelsen et al.'s reported automatic monitoring system for continuous monitoring of $\mathrm{Zn}$ and Iron concentrations (Reprinted with permission from [96] Copyright (C) John Wiley and Sons).

metal accumulated in the sample during the resin equilibration, prior to voltammetric analysis [102]. Detection limits for $\mathrm{Cu}(\mathrm{II}), \mathrm{Pb}(\mathrm{II})$, and $\mathrm{Cd}$ (II) are 20,10 , and $60 \mathrm{pmol} \mathrm{L}^{-1}$, respectively, with an accumulation time of $1 \mathrm{~h}$ using square wave anodic stripping voltammetry based on CGIME [105].

More recently, an improved VIP called the Multi Physical Chemical Profiler (MPCP) has been developed for in situ monitoring of trace metal species in various estuaries and coastal seawaters [106]. The manifold of MCPC is shown in Fig. 9(B). Compared to the VIP system, MCPC consists of three different flow-through cells with their own fluidic systems. One cell is equipped with CGIME and another two cells are equipped with GIME. CGIME is used to obtain the concentration of free metal ions. One GIME in channel 1 is used to measure the concentration of dynamic metal species. The GIME coupled with a FIA for automatic on-line sample pretreatment in channel 3 is used to obtain the total extractable metal concentration by complexing with strong triethyleneteramine followed by acidification and heating. Subtracting the dynamic metal species from the total extractable metal concentration reveals the concentration of metal bound to particles and colloids $[102,106]$. MCPC has been successfully used in $\mathrm{Cu}$ and $\mathrm{Pb}$ speciation analysis in the Po estuary of the Adriatic Sea [106]. VIP and MCPC have been shown to provide reliable, real-time monitoring of metals and their species with less than $10 \%$ variations over a continuous field survey for up to 8 days without renewal of the sensor [104,106], and they provide an exciting new platform for real-time monitoring of trace $\mathrm{Fe}$ and its species in seawater in the near future.

Aside from the in situ sensors described above which are mostly used for trace metal analysis, there have latest developments in in situ sensors 

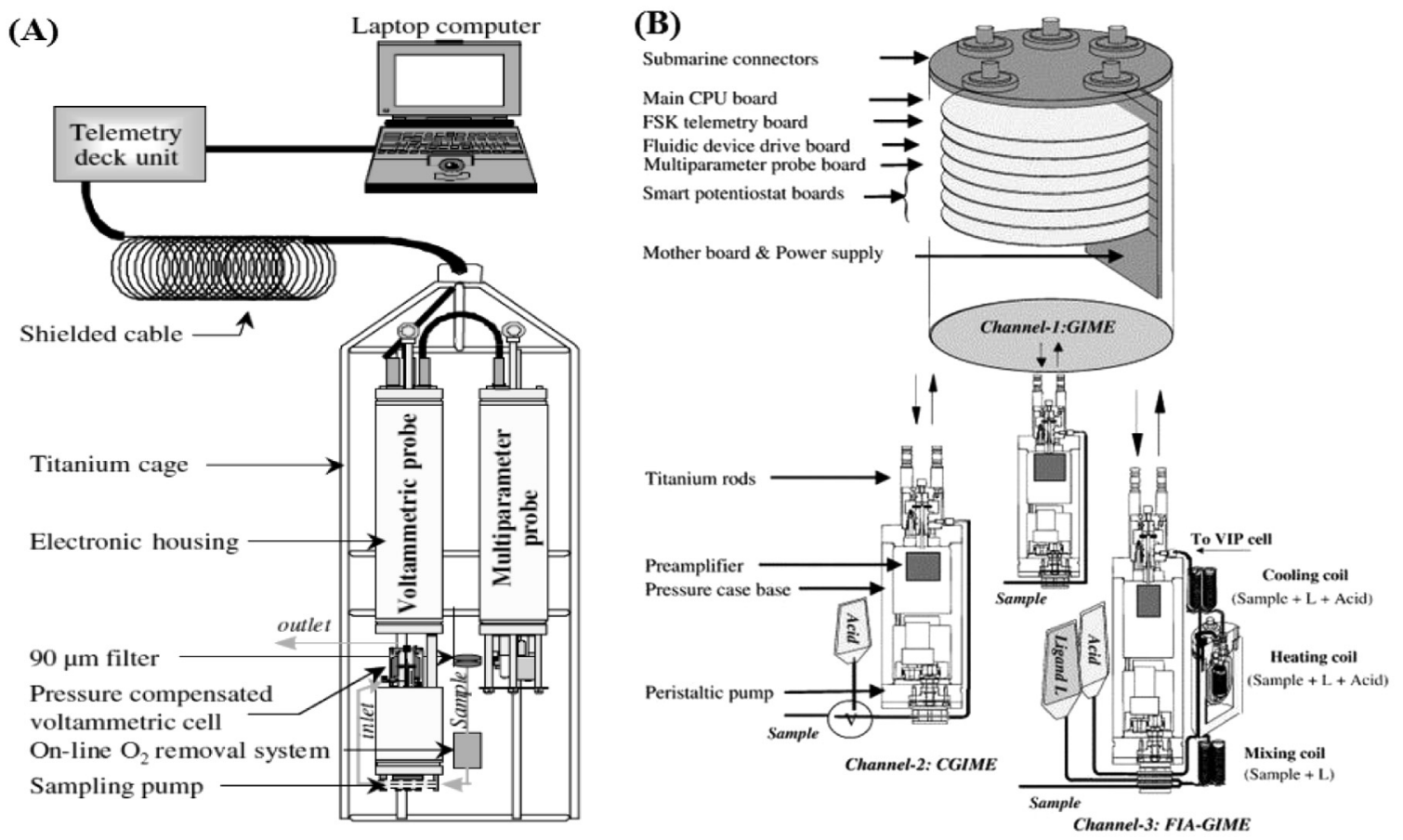

Fig. 9. (A) The manifold of a VIP system (Reprinted with permission from [103] Copyright @ John Wiley and Sons), and (B) a MCPC system (Reprinted with permission from [106] Copyright (C) Elsevier).

based on new strategies for Fe determination in seawater for low cost and reliable long-term monitoring. Chung Chun Lam et al. [107] described an optical sensor in 2006 that overcome the issues of the matrix interference with seawater, biofouling, and long-term stability, etc. They achieved a detection limit of $40 \mathrm{pmol} \mathrm{L}^{-1}$ for the direct measurement of Fe(III) with a working range of $50-1000 \mathrm{pmol} \mathrm{L}^{-1}$ using a fluorescence quenching-based siderophore (parabactin) biosensor. Additionally, this in situ sensor had a reproducibility of $6 \%(n=10)$ for $1000 \mathrm{pmol} \mathrm{L}^{-1} \mathrm{Fe}(\mathrm{III})$. Roy et al. [108] designed a device that includes an iron-specific chelating biomolecule, desferrioxamine B (DFB), which is covalently immobilized on a mesoporous silica film. The device can provide an accurate and precise measurement of iron according to the infrared spectral changes of immobilized DFB upon Fe(III) complexation on the surface of a chip exposed to seawater. The detection limit of this device is about $50 \mathrm{pmol} \mathrm{L}^{-1}$ for samples acidified to $\mathrm{pH} 1.7$. This device has been successfully applied for in situ measurement of dissolved iron in subarctic Pacific seawater and can be deployed on an autonomous platform for long-term monitoring of iron in the field.

In 2015, an autonomous spectrophotometric analyzer capable of providing vertical profiles as well as routine in situ determination of dissolved $\mathrm{Fe}(\mathrm{II})$ and $\mathrm{Mn}$ in seawater was proposed by Milani et al. [109]. The determination of Fe(II) was based on the red purple complex formed by $\mathrm{Fe}(\mathrm{II})$ and ferrozine which gave a maximum absorbance at $562 \mathrm{~nm}$. This autonomous spectrophotometric analyzer contained microfluidic chip, pump, valves and electronic components which were fitted into a $15 \mathrm{~cm}$ diameter $\times 32 \mathrm{~cm}$ long cylindrical tube of anodized aluminum. The core of the analyzer was a colorimetric microfluidic chip (Lab-on-a-chip technology) which was manufactured in $8.0 \mathrm{~mm}$ thick tinted poly methyl methacrylate (PMMA). Samples and reagents were injected, mixed and the absorbance of the resulting complexes was measured by microfluidic chip. The analyzer was attached to the CTD frame on a custom made CTD -carousel [110] which had 9 Niskin bottles. Bottles on the rosette were Teflon coated and were used for water sampling at depth. The data system can directly communicate with $\mathrm{Fe} / \mathrm{Mn}$ analyzer in real time via a RS232 port to initiate the measurement at a certain depth. Fe(II) and Mn could be measured with a frequency of up to 12 samples and 6 samples per hour, respectively.
The detection limit for Fe(II) and Mn was $27 \mathrm{nmol} \mathrm{L}^{-1}$ and $28 \mathrm{nmol}$ $\mathrm{L}^{-1}$, respectively. This device showed the advantages of relatively low cost, low power usage, minimal reagent consumption, portability, tolerance to pressure up to at least 170 bars, high precision and high accuracy.

In situ sensors have great potentials for quantifying the spatial and temporal distribution of iron and its species in seawater, which is of great significance in studying iron marine biogeochemistry and the relationship between iron bioavailability and global carbon cycle. Further development is still needed to improve sensor reliability and data accuracy for long-term operation.

\section{Conclusions and future perspective}

The role of iron in the study of the marine biogeochemistry is significant due to the close relationship between iron and phytoplankton in seawater. The determination of iron in water samples, especially in seawater, seems to be perfect example of the connection and positive feedback between laboratory research works and real environmental need, as well as the improvement and evolution of analytical chemistry and marine chemistry. This paper reviews the various analytical methods for determination of iron in seawater from laboratory to in situ measurement based on the sensing strategies of atomic spectrometry, spectrophotometry, chemiluminescence, and voltammetry, etc. Although the excellent performance of determination of iron has been obtained and reported by most of research works in laboratory, it is still necessary to develop accurate analytical methods for determination of iron and its speciation, especially realizing in situ measurement. There is a high demand for the development of new measurement technologies with sensitive and fast detection, minimal sample treatment, or that can be used directly. It is better to carry out in situ determination of trace iron and its species. The VIP system mentioned above can be used for long-term monitoring and the autonomous spectrophotometric analyzer has advantages of low cost, low maintenance. The aforementioned techniques clearly show that there is a huge potential for realizing in situ measurements of iron in seawater. Further development is still needed to carry out reliable and long-term operations, because long- 
term stability, fouling by organic matters/biofouling and sample treatment are the challenges that need to be overcome.

There is an urgent demand for new sensing methods and in situ measurement devices that can be operated remotely with wireless technologies for real-time iron and iron speciation analysis, and there are promising signs for future development of more reliable and longterm in situ iron sensing platforms, as such information is critical to the study of marine biogeochemistry and global carbon cycle.

\section{Acknowledgements}

This work was financially supported by the Youth Innovation Promotion Association (2011170) and the Equipment Development Project of Chinese Academy of Sciences (YZ201558). We thank MogoEdit for its linguistic assistance during the preparation of this manuscript.

\section{Appendix A. Supplementary material}

Supplementary data associated with this article can be found in the online version at http://dx.doi.org/10.1016/j.talanta.2018.05.071.

\section{References}

[1] K.S. Johnson, R.M. Gordon, K.H. Coale, What controls dissolved iron concentrations in the world ocean? Authors' closing comments, Mar. Chem. 57 (1997) 181-186.

[2] F.J. Millero, W. Yao, J. Aicher, The speciation of Fe(II) and Fe(III) in natural waters, Mar. Chem. 50 (1995) 21-39.

[3] D.R. Turner, K.A. Hunter, The Biogeochemistry of Iron in Seawater, Wiley, Chichester, 2001.

[4] M.J. Behrenfeld, Z.S. Kolber, Widespread iron limitation of phytoplankton in the South Pacific, Ocean, Sci. 283 (1999) 840-843.

[5] W.G. Sunda, S.A. Huntsman, Iron uptake and growth limitation in oceanic and coastal phytoplankton, Mar. Chem. 50 (1995) 189-206.

[6] M.G. Frías-Espericueta, D. Voltolina, J.I. Osuna-López, Acute toxicity of copper, zinc, iron, and manganese and of the mixtures copper-zinc and iron-manoanese to whiteleg shrimp Litopenaeus vannamei postlarvae, Bull. Environ. Contam. Tox. 71 (2003) 68-74.

[7] Q. Zhou, Y. Zhang, H.F. Peng, C.H. Ke, H.Q. Huang, Toxicological responses of the hard clam Meretrix meretrix exposed to excess dissolved iron or challenged by Vibrio parahaemolyticus, Aquat. Toxicol. 156 (2014) 240-247.

[8] P.J. Worsfold, M.C. Lohan, S.J. Ussher, A.R. Bowie, Determination of dissolved iron in seawater: a historical review, Mar. Chem. 166 (2014) 25-35.

[9] S.J. Ussher, E.P. Achterberg, G. Sarthou, P. Laan, H.J. de Baar, P.J. Worsfold, Distribution of size fractionated dissolved iron in the Canary Basin, Mar. Environ. Res. 70 (2010) 46-55.

[10] M. Jiang, K.A. Barbeau, K.E. Selph, C.I. Measures, K.N. Buck, F. Azam, B. Greg Mitchell, M. Zhou, The role of organic ligands in iron cycling and primary productivity in the Antarctic Peninsula: a modeling study, Deep-Sea Res. 90 (Pt II) (2013) 112-133.

[11] M.A. Anderson, F.M.M. Morel, The influence of aqueous iron chemistry on the uptake of iron by the coastal diatom Thalassiosira weissflogii, Limnol. Oceanogr. 27 (1982) 789-813.

[12] F.M. Morel, J.G. Hering, Principles and Applications of Aquatic Chemistry, John Wiley \& Sons, 1993.

[13] X. Liu, F.J. Millero, The solubility of iron in seawater, Mar. Chem. 77 (2002) 43-54.

[14] D.W. O'Sullivan, A.K. Hanson, D.R. Kester, Stopped flow luminol chemiluminescence determination of $\mathrm{Fe}(\mathrm{II})$ and reducible iron in seawater at subnanomolar levels, Mar. Chem. 49 (1995) 65-77.

[15] M. Gledhill, K.N. Buck, The organic complexation of iron in the marine environment: a review, Front. Microbiol. 3 (2012) (Article 69).

[16] K. Kuma, J. Nishioka, K. Matsunaga, Controls on iron(III) hydroxide solubility in seawater: the influence of $\mathrm{pH}$ and natural organic chelators, Limnol. Oceanogr. 41 (1996) 396-407.

[17] J. Leigh-Smith, A. Reichelt-Brushett, A.L. Rose, The characterization of iron(III) in seawater and related toxicity to early life stages of scleractinian corals, Environ. Toxicol. Chem. 9999 (2017) 1-11.

[18] X. Liu, F.J. Millero, The solubility of iron in seawater, Mar. Chem. 77 (2002) 43-54.

[19] J.H. Martin, Glacial-interglacial $\mathrm{CO}_{2}$ change: the iron hypothesis, Paleoceanography 5 (1990) 1-13.

[20] L.M. Laglera, J. Santos-Echeandía, S. Caprara, D. Monticelli, Quantification of iron in seawater at the low picomolar range based on optimization of bromate/ammonia/dihydroxynaphtalene system by catalytic adsorptive cathodic stripping voltammetry, Anal. Chem. 85 (2013) 2486-2492.

[21] G. Cutter, P. Andersson, L. Codispoti, P. Croot, R. Francois, M. Lohan, H. Obata, M. Rutgers vd Loeff, Sampling and sample-handling protocols for GEOTRACES cruises, GEOTRACES (2010) (VI46-56).

[22] C.N. Hunter, R.M. Gordon, S.E. Fitzwater, K.H. Coale, A rosette system for the collection of trace metal clean seawater, Limnol. Oceanogr. 41 (1996) 1367-1372.

[23] H. Obata, C.M.G. van den Berg, Determination of picomolar levels of iron in seawater using catalytic cathodic stripping voltammetry, Anal. Chem. 73 (2001) 2522-2528.

[24] M. Gledhill, C.M.G. van den Berg, Measurement of the redox speciation of iron in seawater by catalytic cathodic stripping voltammetry, Mar. Chem. 50 (1995) $51-61$.

[25] A.P. Aldrich, C.M.G. van den Berg, Determination of iron and its redox speciation in seawater using catalytic cathodic stripping voltammetry, Electroanalysis 10 (1998) 369-373.

[26] K.W. Bruland, R.P. Franks, G.A. Knauer, J.H. Martin, Sampling and analytical methods for the determination of copper, cadmium, zinc, and nickel at the nanogram per liter level in sea water, Anal. Chim. Acta 105 (1979) 233-245.

[27] W.M. Landing, K.W. Bruland, The contrasting biogeochemistry of iron and manganese in the Pacific Ocean, Geochim. Cosmochim. Acta 51 (1987) 29-43.

[28] Y. Sohrin, S. Iwamoto, S. Akiyama, T. Fujita, T. Kugii, H. Obata, E. Nakayama, S. Goda, Y. Fujishima, H. Hasegawa, Determination of trace elements in seawater by fluorinated metal alkoxide glass-immobilized 8-hydroxyquinoline concentration and high-resolution inductively coupled plasma mass spectrometry detection, Anal. Chim. Acta 363 (1998) 11-19.

[29] P.M. Saager, H.J. De Baar, P.H. Burkill, Manganese and iron in Indian Ocean waters, Geochim. Cosmochim. Acta 53 (1989) 2259-2267.

[30] D.V. Biller, K.W. Bruland, Analysis of Mn, Fe, Co, Ni, Cu, Zn, Cd, and Pb in seawater using the Nobias-chelate PA1 resin and magnetic sector inductively coupled plasma mass spectrometry (ICP-MS), Mar. Chem. 130 (2012) 12-20.

[31] A. Milne, W. Landing, M. Bizimis, P. Morton, Determination of Mn, Fe, Co, Ni, Cu, $\mathrm{Zn}, \mathrm{Cd}$ and $\mathrm{Pb}$ in seawater using high resolution magnetic sector inductively coupled mass spectrometry (HR-ICP-MS), Anal. Chim. Acta 665 (2010) 200-207.

[32] J. Wu, E.A. Boyle, Determination of iron in seawater by high-resolution isotope dilution inductively coupled plasma mass spectrometry after $\mathrm{Mg}(\mathrm{OH})_{2}$ coprecipitation, Anal. Chim. Acta 367 (1998) 183-191.

[33] S. Sadeghi, V. Ashoori, Iron species determination by task-specific ionic liquidbased in situ solvent formation dispersive liquid-liquid microextraction combined with flame atomic absorption spectrometry, J. Sci. Food Agr. 97 (2017) 4635-4642.

[34] J. Wu, Determination of picomolar iron in seawater by double $\mathrm{Mg}(\mathrm{OH})_{2}$ precipitation isotope dilution high-resolution ICPMS, Mar. Chem. 103 (2007) 370-381.

[35] T. Minami, W. Konagaya, L. Zheng, S. Takano, M. Sasaki, R. Murata, Y. Nakaguchi, Y. Sohrin, An off-line automated preconcentration system with ethylenediaminetriacetate chelating resin for the determination of trace metals in seawater by high-resolution inductively coupled plasma mass spectrometry, Anal. Chim. Acta 854 (2015) 183-190.

[36] L. Cooper, Iron in the sea and in marine plankton, Proc. R. Soc. Ser. B-Biol. Sci. 118 (1935) 419-438.

[37] L. Cooper, The distribution of iron in the waters of the western English Channel, J. Mar. Biol. Assoc. U.K. 27 (1948) 279-313.

[38] N.W. Rakestraw, H.E. Mahncke, E.F. Beach, Determination of iron in sea water, Ind. Eng. Chem. Anal. 8 (1936) 136-138.

[39] F. Armstrong, The iron content of sea water, J. Mar. Biol. Assoc. U.K. 36 (1957) 509-517.

[40] K. Grasshoff, Determination of nutrients, Method Sea Anal. (1983) 125-187.

[41] G. Topping, Concentrations of $\mathrm{Mn}, \mathrm{Co}, \mathrm{Cu}, \mathrm{Fe}$, and $\mathrm{Zn}$ in Northern Indian ocean and Arabian sea, J. Mar. Res. 27 (1969) 318-326.

[42] W.M. Landing, C. Haraldsson, N. Paxeus, Vinyl polymer agglomerate based transition metal cation-chelating ion-exchange resin containing the 8-hydroxyquinoline functional group, Anal. Chem. 58 (1986) 3031-3035.

[43] M.P. Hurst, K.W. Bruland, An investigation into the exchange of iron and zinc between soluble, colloidal, and particulate size-fractions in shelf waters using lowabundance isotopes as tracers in shipboard incubation experiments, Mar. Chem. 103 (2007) 211-226.

[44] M.C. Lohan, A.M. Aguilar-Islas, R.P. Franks, K.W. Bruland, Determination of iron and copper in seawater at $\mathrm{pH} 1.7$ with a new commercially available chelating resin, NTA Superflow, Anal. Chim. Acta 530 (2005) 121-129.

[45] L.L. Stookey, Ferrozine-a new spectrophotometric reagent for iron, Anal. Chem. 42 (1970) 779-781.

[46] S. Blain, P. Treguer, Iron(II) and iron(III) determination in sea water at the nanomolar level with selective on-line preconcentration and spectrophotometric determination, Anal. Chim. Acta 308 (1995) 425-432.

[47] R.J. Hudson, D.T. Covault, F.M. Morel, Investigations of iron coordination and redox reactions in seawater using ${ }^{59} \mathrm{Fe}$ radiometry and ion-pair solvent extraction of amphiphilic iron complexes, Mar. Chem. 38 (1992) 209-235.

[48] H. Obata, H. Karatani, E. Nakayama, Automated determination of iron in seawater by chelating resin concentration and chemiluminescence detection, Anal. Chem. 65 (1993) 1524-1528.

[49] C. Measures, J. Yuan, J. Resing, Determination of iron in seawater by flow injection analysis using in-line preconcentration and spectrophotometric detection, Mar. Chem. 50 (1995) 3-12.

[50] M.C. Lohan, A.M. Aguilar-Islas, K.W. Bruland, Direct determination of iron in acidified ( $\mathrm{pH}$ 1.7) seawater samples by flow injection analysis with catalytic spectrophotometric detection: application and intercomparison, Limnol. Oceanogr.-Methods 4 (2006) 164-171.

[51] S. Lunvongsa, M. Oshima, S. Motomizu, Determination of total and dissolved amount of iron in water samples using catalytic spectrophotometric flow injection analysis, Talanta 68 (2006) 969-973.

[52] Z.F. Zhang, H. Cui, C.Z. Lai, L.J. Liu, Gold nanoparticle-catalyzed luminol chemiluminescence and its analytical applications, Anal. Chem. 77 (2005) 3324-3329.

[53] D.W. O'Sullivan, A.K. Hanson Jr., D.R. Kester, Stopped flow luminol chemiluminescence determination of $\mathrm{Fe}(\mathrm{II})$ and reducible iron in seawater at subnanomolar 
levels, Mar. Chem. 49 (1995) 65-77.

[54] D.W. King, H.A. Lounsbury, F.J. Millero, Rates and mechanism of Fe(II) oxidation at nanomolar total iron concentrations, Environ. Sci. Technol. 29 (1995) 818-824.

[55] V.A. Elrod, K.S. Johnson, K.H. Coale, Determination of subnanomolar levels of iron(II) and total dissolved iron in seawater by flow injection and analysis with chemiluminescence detection, Anal. Chem. 63 (1991) 893-898.

[56] S. Hirata, H. Yoshihara, M. Aihara, Determination of iron(II) and total iron in environmental water samples by flow injection analysis with column preconcentration of chelating resin functionalized with N-hydroxyethylethylenediamine ligands and chemiluminescence detection, Talanta 49 (1999) 1059-1067.

[57] A.L. Rose, T.D. Waite, Kinetic model for Fe(II) oxidation in seawater in the absence and presence of natural organic matter, Environ. Sci. Technol. 36 (2002) 433-444.

[58] A.R. Bowie, E.P. Achterberg, R.F.C. Mantoura, P.J. Worsfold, Determination of sub-nanomolar levels of iron in seawater using flow injection with chemiluminescence detection, Anal. Chim. Acta 361 (1998) 189-200.

[59] M. Štulíková, F. Vydra, Voltammetry with disk electrodes and its analytical application: IV. The voltammetry of iron(III) at the glassy carbonrotating disk electrode in acid-media, J. Electroanal. Chem. 38 (1972) 349-357.

[60] E.M. Ghoneim, Simultaneous determination of $\mathrm{Mn}(\mathrm{II}), \mathrm{Cu}(\mathrm{II})$ and $\mathrm{Fe}(\mathrm{III})$ as 2-(5'bromo-2'-pyridylazo)-5-diethylaminophenol complexes by adsorptive cathodic stripping voltammetry at a carbon paste electrode, Talanta 82 (2010) 646-652.

[61] H. Han, D. Pan, C. Wang, R. Zhu, Controlled synthesis of dendritic gold nanostructures by graphene oxide and their morphology-dependent performance for iron detection in coastal waters, RSC Adv. 7 (2017) 15833-15841.

[62] X. Hu, D. Pan, M. Lin, H. Han, F. Li, Graphene oxide-assisted synthesis of bismuth nanosheets for catalytic stripping voltammetric determination of iron in coastal waters, Microchim. Acta 183 (2016) 855-861.

[63] F. Li, D. Pan, M. Lin, H. Han, X. Hu, Q. Kang, Electrochemical determination of iron in coastal waters based on ionic liquid-reduced graphene oxide supported gold nanodendrites, Electrochim. Acta 176 (2015) 548-554.

[64] M. Lin, H. Han, D. Pan, H. Zhang, Z. Su, Voltammetric determination of total dissolved iron in coastal waters using a glassy carbon electrode modified with reduced graphene oxide, Methylene Blue and gold nanoparticles, Microchim. Acta 182 (2015) 805-813.

[65] M. Lin, D. Pan, X. Hu, H. Han, F. Li, Titanium carbide nanoparticles/ion-exchange polymer-based sensor for catalytic stripping determination of trace iron in coastal waters, Sens. Actuator B-Chem. 219 (2015) 164-170.

[66] C.M.G. van den Berg, Z.Q. Huang, Determination of iron in seawater using cathodic stripping voltammetry preceded by adsorptive collection with the hanging mercury drop electrode, J. Electroanal. Chem. 177 (1984) 269-280.

[67] E.L. Rue, K.W. Bruland, Complexation of iron(III) by natural organic ligands in the Central North Pacific as determined by a new competitive ligand equilibration/ adsorptive cathodic stripping voltammetric method, Mar. Chem. 50 (1995) $117-138$.

[68] M. Gledhill, C.M.G. van den Berg, Determination of complexation of iron(III) with natural organic complexing ligands in seawater using cathodic stripping voltammetry, Mar. Chem. 47 (1994) 41-54.

[69] P. Croot, M. Johansson, Determination of iron speciation by cathodic stripping voltammetry in seawater using the competing ligand 2-(2-Thiazolylazo)-p-cresol (TAC), Electroanalysis 12 (2000) 565-576.

[70] C.M.G. van den Berg, Chemical speciation of iron in seawater by cathodic stripping voltammetry with dihydroxynaphthalene, Anal. Chem. 78 (2006) 156-163.

[71] R.F. Palmer, S. Blanchard, Z. Stein, D. Mandell, C. Miller, Environmental mercury release, special education rates, and autism disorder: an ecological study of Texas, Health Place. 12 (2006) 203-209.

[72] R. Segura, M.I. Toral, V. Arancibia, Determination of iron in water samples by adsorptive stripping voltammetry with a bismuth film electrode in the presence of 1-(2-piridylazo)-2-naphthol, Talanta 75 (2008) 973-977.

[73] M. Lin, D. Pan, X. Hu, F. Li, H. Han, A tin-bismuth alloy electrode for the cathodic stripping voltammetric determination of iron in coastal waters, Anal. MethodsU.K. 7 (2015) 5169-5174.

[74] A. Bobrowski, K. Nowak, J. Zarębski, Application of a bismuth film electrode to the voltammetric determination of trace iron using a $\mathrm{Fe}(\mathrm{III})-\mathrm{TEA}-\mathrm{BrO}_{3}{ }^{-}$catalytic system, Anal. Bioanal. Chem. 382 (2005) 1691-1697.

[75] Y. Zhu, D. Pan, X. Hu, H. Han, M. Lin, C. Wang, An electrochemical sensor based on reduced graphene oxide/gold nanoparticles modified electrode for determination of iron in coastal waters, Sens. Actuator B-Chem. 243 (2017) 1-7.

[76] M. Lin, D. Pan, Y. Zhu, X. Hu, H. Han, C. Wang, Dual-nanomaterial based electrode for voltammetric stripping of trace Fe(II) in coastal waters, Talanta 154 (2016) 127-133.

[77] S. Pehkonen, Determination of the oxidation states of iron in natural waters. A review, Analyst 120 (1995) 2655-2663.

[78] D. Hutchins, A. Witter, A. Butler, G. Luther III, Differential utilization of chelated iron species by marine phytoplankton taxa, Nature 400 (1999) 858-861.

[79] E.A. Zagatto, Flow Analysis with Spectrophotometric and Luminometric Detection, Handbooks in Analytical Science, 2012, ii-iii.

[80] A.R. Bowie, P.N. Sedwick, P.J. Worsfold, Analytical intercomparison between flow injection-chemiluminescence and flow injection-spectrophotometry for the determination of picomolar concentrations of iron in seawater, Limnol. Oceanogr. Methods 2 (2004) 42-54.

[81] D.W. King, J. Lin, D.R. Kester, Spectrophotometric determination of iron(II) in seawater at nanomolar concentrations, Anal. Chim. Acta 247 (1991) 125-132.

[82] D.W. O'Sullivan, A.K. Hanson, W.L. Miller, D.R. Kester, Measurement of Fe(II) in surface water of the equatorial Pacific, Limnol. Oceanogr. 36 (1991) 1727-1741.

[83] J.-Z. Zhang, C. Kelble, F.J. Millero, Gas-segmented continuous flow analysis of iron in water with a long liquid waveguide capillary flow cell, Anal. Chim. Acta 438
(2001) 49-57

[84] Y. Huang, D. Yuan, Y. Zhu, S. Feng, Real-time redox speciation of iron in estuarine and coastal surface waters, Environ. Sci. Technol. 49 (2015) 3619-3627.

[85] Y. Huang, D. Yuan, M. Dai, Y. Liu, Reverse flow injection analysis method for catalytic spectrophotometric determination of iron in estuarine and coastal waters: a comparison with normal flow injection analysis, Talanta 93 (2012) 86-93.

[86] A.R. Bowie, E.P. Achterberg, P.N. Sedwick, S. Ussher, P.J. Worsfold, Real-time monitoring of picomolar concentrations of iron(II) in marine waters using automated flow injection-chemiluminescence instrumentation, Environ. Sci. Technol. 36 (2002) 4600-4607.

[87] S.P. Hansard, W.M. Landing, Determination of iron(II) in acidified seawater samples by luminol chemiluminescence, Limnol. Oceanogr.-Methods 7 (2009) 222-234.

[88] M. Klunder, P. Laan, R. Middag, H. De Baar, J. Van Ooijen, Dissolved iron in the Southern Ocean (Atlantic sector), Deep-Sea Res. 58 (Pt II) (2011) 2678-2694.

[89] V. Cannizzaro, A.R. Bowie, A. Sax, E.P. Achterberg, P.J. Worsfold, Determination of cobalt and iron in estuarine and coastal waters using flow injection with chemiluminescence detection presented at SAC 99, Dublin, Ireland, July 25-30, 1999, Analyst 125 (2000) 51-57.

[90] H.M. Oliveira, M.M. Grand, J. Ruzicka, C.I. Measures, Towards chemiluminescence detection in micro-sequential injection lab-on-valve format: a proof of concept based on the reaction between Fe(II) and luminol in seawater, Talanta 133 (2015) $107-111$.

[91] E.P. Achterberg, C.M.G. van den Berg, In-line ultraviolet-digestion of natural water samples for trace metal determination using an automated voltammetric system, Anal. Chim. Acta 291 (1994) 213-232.

[92] E.P. Achterberg, C.M.G. van den Berg, Automated voltammetric system for shipboard determination of metal speciation in sea water, Anal. Chim. Acta 284 (1994) 463-471.

[93] K.Z. Brainina, N. Malakhova, N.Y. Stojko, Stripping voltammetry in environmental and food analysis, Fresenius' J. Anal. Chem. 368 (2000) 307-325.

[94] K.A. Howell, E.P. Achterberg, C.B. Braungardt, A.D. Tappin, D.R. Turner, P.J. Worsfold, The determination of trace metals in estuarine and coastal waters using a voltammetric in situ profiling system, Analyst 128 (2003) 734-741.

[95] E.P. Achterberg, C. Braungardt, Stripping voltammetry for the determination of trace metal speciation and in-situ measurements of trace metal distributions in marine waters, Anal. Chim. Acta 400 (1999) 381-397.

[96] Ø. Mikkelsen, K. Strasunskiene, S. Skogvold, K.H. Schrøder, C.C. Johnsen, M. Rydningen, P. Jonsson, A. Jonsson, Automatic voltammetric system for continuous trace metal monitoring in various environmental samples, Electroanalysis 19 (2007) 2085-2092.

[97] G.W. Luther, B.T. Glazer, S. Ma, R.E. Trouwborst, T.S. Moore, E. Metzger, C. Kraiya, T.J. Waite, G. Druschel, B. Sundby, Use of voltammetric solid-state (micro) electrodes for studying biogeochemical processes: laboratory measurements to real time measurements with an in situ electrochemical analyzer (ISEA), Mar. Chem. 108 (2008) 221-235.

[98] M. Taillefert, A. Bono, G. Luther, Reactivity of freshly formed Fe(III) in synthetic solutions and (pore) waters: voltammetric evidence of an aging process, Environ. Sci. Technol. 34 (2000) 2169-2177.

[99] V. Cerdà, C. Pons, Multicommutated flow techniques for developing analytical methods, TrAC-Trend Anal. Chem. 25 (2006) 236-242.

[100] L.O. Leal, R. Forteza, V. Cerda, Speciation analysis of inorganic arsenic by a multisyringe flow injection system with hydride generation-atomic fluorescence spectrometric detection, Talanta 69 (2006) 500-508.

[101] C. Calderilla, F. Maya, V. Cerda, L.O. Leal, 3D printed device including disk-based solid-phase extraction for the automated speciation of iron using the multisyringe flow injection analysis technique, Talanta 175 (2017) 463-469.

[102] M.L. Tercier-Waeber, M. Taillefert, Remote in situ voltammetric techniques to characterize the biogeochemical cycling of trace metals in aquatic systems, J. Environ. Monit. 10 (2008) 30-54.

[103] M.L. Tercier, J. Buffle, F. Graziottin, A novel voltammetric in-situ profiling system for continuous real-time monitoring of trace elements in natural waters, Electroanalysis 10 (1998) 355-363.

[104] M.L. Tercier-Waeber, C. Belmont-Hébert, J. Buffle, Real-time continuous Mn(II) monitoring in lakes using a novel voltammetric in situ profiling system, Environ. Sci. Technol. 32 (1998) 1515-1521.

[105] S. Noël, M.L. Tercier-Waeber, L. Lin, J. Buffle, O. Guenat, M. Koudelka-Hep, Integrated microanalytical system for simultaneous voltammetric measurements of free metal ion concentrations in natural waters, Electroanalysis 18 (2006) 2061-2069.

[106] M.L. Tercier-Waeber, F. Confalonieri, G. Riccardi, A. Sina, S. Nöel, J. Buffle F. Graziottin, Multi Physical-chemical profiler for real-time in situ monitoring of trace metal speciation and master variables: development, validation and field applications, Mar. Chem. 97 (2005) 216-235.

[107] C.K. Chung Chun Lam, T.D. Jickells, D.J. Richardson, D.A. Russell, Fluorescencebased siderophore biosensor for the determination of bioavailable iron in oceanic waters, Anal. Chem. 78 (2006) 5040-5045.

[108] E.G. Roy, C. Jiang, M.L. Wells, C. Tripp, Determining subnanomolar iron concentrations in oceanic seawater using a siderophore-modified film analyzed by infrared spectroscopy, Anal. Chem. 80 (2008) 4689-4695.

[109] A. Milani, P.J. Statham, M.C. Mowlem, D.P. Connelly, Development and application of a microfluidic in-situ analyzer for dissolved Fe and Mn in natural waters, Talanta 136 (2015) 15-22.

[110] E. Strady, C. Pohl, E.V. Yakushev, S. Kruger, U. Hennings, PUMP-CTD-System for trace metal sampling with a high vertical resolution. A test in the Gotland Basin, Baltic Sea, Chemosphere 70 (2008) 1309-1319. 